\title{
Inhaltsverzeichnis / Table of Contents
}

Vorwort / Preface

JOHN DUFFY

Proclus the Philosopher and A Weapon of Mass Destruction:

History or Legend? 1

StePhANOS EFthyMiAdis / J. M. FEATHERSTONE

Establishing a Holy Lineage: Theodore the Stoudite's Funerary

Catechism for His Mother (BHG 2422)

FRITZ FELGENTREU

Aufbau und Erzähltechnik im Epitaphios auf Kaiser Julian.

Zur Kompositionskunst des Libanios

NiELS GAUL

The Partridge's Purple Stockings: Observations on the

Historical, Literary and Manuscript Context of Pseudo-Kodinos'

Handbook on Court Ceremonial

LARS HOFFMANN

Geschichtsschreibung oder Rhetorik? Zum logos parakletikos bei

Leon Diakonos

GRAMMATIKI KARLA

Die Klage über die zerstörte Stadt Nikomedeia bei Libanios im Spiegel der Mimesis

SOFIA KOTZABASSI

Bemerkungen zu dem Enkomion des Joseph Studites auf den

heiligen Demetrios (BHG 535)

StAVROS I. KOUROUSES



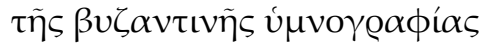


GERNOT KRAPINGER

Die Bienen des armen Mannes in Antike und Mittelalter

TILMAN KRISCHER

Die materiellen Voraussetzungen des geistigen Lebens in Byzanz -

Handelskontakte mit Ostafrika, ihre Vorgeschichte

und ihre Nachwirkungen

RALPH-JOHANNES LILIE

Fiktive Realität: Basileios II. und Konstantinos VIII. in der

„Chronographia“ des Michael Psellos

ANTONY LITTLEWOOD

Vegetal and Animal Imagery in the History of Niketas Choniates

MARINA LOUKAKI

Notes sur l'activité d'Aréthas comme rhéteur de la cour de Léon VI

PRZEMYSŁAW MARCINIAK

Byzantine Theatron - A Place of Performance?

KARIN METZLER

Pagane Bildung im christlichen Byzanz: Basileios von Kaisareia,

Michael Psellos und Theodoros Metochites

DIETMAR NAJOCK

Unechtes und Zweifelhaftes unter den Deklamationen

des Libanios - die statistische Evidenz

STRATIS PAPAIOANNOU

On the Stage of Eros: Two Rhetorical Exercises

by Nikephoros Basilakes

THOMAS PRATSCH

Rhetorik in der byzantinischen Hagiographie:

Die Prooimia der Heiligenviten.

ANDREAS RHOBY

Aspekte des Fortlebens des Gregor von Nazianz in

byzantinischer und postbyzantinischer Zeit

ANDREW F. STONE

Aurality in the Panegyrics of Eustathios of Thessaloniki 
IDA TOTH

Rhetorical Theatron in Late Byzantium: The Example of

Palaiologan Imperial Orations

ERICH TRAPP

Zum Wortschatz des Theodor Studites

RUTH WEBB

The Model Ekphraseis of Nikolaos the Sophist as Memory Images 463

Siglenverzeichnis / List of Sigla

Indices

481

Autorinnen und Autoren / List of Contributors 515 
